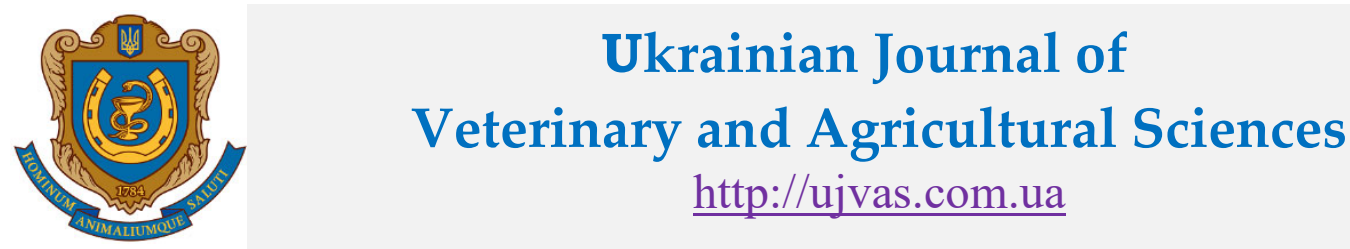

Stepan Gzhytskyi National University of Veterinary Medicine and Biotechnologies Lviv

\begin{tabular}{l|l|l} 
original article & UDC 636.03 & doi: $10.32718 /$ ujvas2-2.08
\end{tabular}

\title{
Zoohygienic and economic aspects of construction and operation of the average complex for the conservation of wild haves
}

\author{
V. O. Pepko ${ }^{1}$, T. A. Velesik², R. M. Sachuk ${ }^{3}$, Yu. M. Mandigra ${ }^{3}$, S. V. Zhigalyuk ${ }^{3}$ \\ ${ }^{1}$ Rivne State Humanities University, Plastova Str., 29a, Rivne, 33028, Ukraine \\ ${ }^{2}$ National University of Water and Environmental Engineering, O. Novak Str., 75, Rivne, 33002, Ukraine \\ ${ }^{3}$ Research Epizootology Station IVM NAAS, Knyazya Volodymyra Str., 18, Rivne, 33028, Ukraine
}

\begin{tabular}{|c|}
\hline $\begin{array}{l}\text { Article info } \\
\text { Received } 23.09 .2019 \\
\text { Received in revised form } \\
\quad 24.10 .2019 \\
\text { Accepted } 25.10 .2019\end{array}$ \\
\hline $\begin{array}{l}\text { Correspondence author } \\
\text { Roman Sachuk } \\
\text { Tel.: +38-097-671-90-63 } \\
\text { E-mail: sachuk.08@ukr.net }\end{array}$ \\
\hline $\begin{array}{l}\text { C) } 2019 \text { Pepko V. O. et al. This is an } \\
\text { open-access article distributed under } \\
\text { the terms of the Creative Commons } \\
\text { Attribution License, which permits } \\
\text { unrestricted use, distribution, and } \\
\text { reproduction in any medium, } \\
\text { provided the original author and } \\
\text { source are credited. }\end{array}$ \\
\hline$(\mathrm{cc}) \mathrm{BY}$ \\
\hline $\begin{array}{ll}\text { Contents } & \\
\text { 1. Introduction .................. } & 37 \\
\text { 2. Materials and methods ...... } & 38 \\
\text { 3. Results and discussion ...... } & 38 \\
\text { 4. Conclusions .................. } & 40 \\
\text { References ................... } & 40\end{array}$ \\
\hline
\end{tabular}

\begin{abstract}
The formation and development of a market-based management system for hunting in Ukraine require fundamentally new approaches to the organization of business management. The practical implementation of any commercial project is significantly complicated without a previously developed zoo-hygienically and economically sound business plan. The purpose of the study was to improve measures for the organization and operation of the aviary complex for the maintenance and breeding of wild ungulates. The work used sanitary-hygienic methods of scientific research, in addition applied theoretical analysis of scientific literary sources, synthesis, generalization, comparison, concretization. According to the results of the research on the basis of zoohygienic norms and economic calculations, the project of organization and development of the aviation complex "Hunting farm "Polisske-Sarny" is located near the village. Terrible of Sarnensky District on the lands of the State Forest Fund of Strashevsky Forestry of SE Sarnenskoye Forestry. The area of the enclosure is 146.7 ha, which is divided into 4 contours to hold the fallow deer, red deer, wild boar and European mouflon. Proposed measures for construction and operation of the aviary complex for keeping wild ungulates (fallow deer and mouflon European, as well as wild boar and red deer), owned by the Polisske-Sarny Hunting Enterprise. The total amount of capital investments for the creation of a cage for the maintenance of wild animals, including the cost of construction, purchase of livestock breeders is from 1337.1 thousand UAH. Due to the sale of animals to other farms, you can receive from 280-320 thousand UAH income per year. Taking into account the initial investments for the establishment of the aviary complex, the payback period is 3 years.
\end{abstract}

Key words: deer noble, wild boar, European mouflon, retention, fallow deer, aviary, construction project, investments, profit.

\section{Citation:}

Pepko, V. O., Velesik, T. A., Sachuk, R. M., Mandigra, Yu. M., \& Zhigalyuk, S. V. (2019). Zoohygienic and economic aspects of construction and operation of the average complex for the conservation of wild haves. Ukrainian Journal of Veterinary and Agricultural Sciences, 2(2), 37-40.

\section{Introduction}

The leading goal of the modern hunting economy is to increase the efficiency of activity in the industry, to create the infrastructure for the proper service of hunters, the rational use and reproduction of wild fauna resources. The aviary breeding of animals is an integral part of the complex hunting economy, which can be guaranteed to ensure the production of animals.

General zoohygienic requirements for aviaries of any area are: compliance with the requirements of legislation in the field of nature protection and hunting, recruitment and training of personnel (preferably in specialized educational institutions or through internships in operating farms), the import of uterine livestock breeding measures, keeping appropriate documentation, and their economic justification will provide.
In the hunting system of Ukraine, in most cases, aviaries are created on a small area (up to 10 hectares) and are auxiliary economic objects that are intended for temporary overburden before release to the land, obtaining a litter for its further implementation, etc. (Bilyi, 2007).

Comparison of growth rates, disease resistance, water needs, food efficiency, pasture load indicate that wild animals have a predominance of domestic animals when growing for meat production (Volokh, 2001; 2015; 2016).

Farm (aviary) breeding of ungulates is an important element in the development of hunting and agriculture (as an alternative to traditional animal husbandry), as well as ecotourism (Evtushevskyi, 2012).

Among the species of the Reindeer (Cervuse) family, the most common objects of keeping and breeding in the aviaries are the red deer (Cervus elaphus L, 1758), the red-tailed 
deer (Cervus nippon Temminck, 1838) and the fallow deer (Cervus dama L, 1758).

The intensive breeding of animals, increasing their livestock numbers, productivity and growth rates require the development and implementation of a comprehensive set of measures, which is envisaged by the General Veterinary Prevention Plan (SWF), which is the basis for the development of specific veterinary production technology.

The purpose of the study is to improve measures for the organization and operation of the aviary complex for the maintenance and breeding of wild ungulates.

\section{Materials and methods}

The experiments were conducted in an aviary complex owned by the "Polisske-Sarny Hunting Enterprise" LLC (Sarny District, Rivne Region) on the basis of effective intensive technology.

The work used sanitary-hygienic methods of scientific research, in addition applied theoretical analysis of scientific literary sources, synthesis, generalization, comparison, concretization (Pepko, 2019).

\section{Results and discussion}

Housing Complex LLC Hunting Farm "Polisske-Sarny" is located near the village. Terrible of Sarnensky District on the lands of the State Forest Fund of Strashevsky Forestry of SE Sarnenskoye Forestry.

The area of the enclosure is 146.7 ha, which is divided into 4 contours to hold the fallow deer, red deer, wild boar and European mouflon. In order to quarantine animals, a quarantine yard of 0.05 hectares has been set up before settling in the aviary.

For the construction of the enclosure enclosure used a special enclosure, mounted on wooden poles and buried in the ground by $30 \mathrm{~cm}$ height of the enclosure is $2.7 \mathrm{~m}$. and immersed in the soil to a depth of $1 \mathrm{~m}$. Previously, the part of the mesh that is immersed in the soil is treated with anticorrosion agents. This prevents the entry into the enclosure of predators (stray dogs, foxes, etc.). When constructing the enclosure, it is necessary to keep the fire breaks laid during the forest management.

In the aviary there are 5 salt pans and 5 feeders, 3 livestock, a line of small minibuses. For the aviary service gates (for the passage of motor vehicles) and doors (for passage of people) are provided, a stationary guard post is equipped. There are barriers in front of the gates and doors.

Therefore, at the initial stage of operation of the aviary complex, it is necessary to attract investments for the construction of the fence, purchase of livestock, remuneration of staff involved in the respective works, transportation costs, etc (Table 1).

The total amount of capital investments for the creation of a cage for keeping wild ungulates, including the cost of construction, purchase of livestock of the captives is from 1337.1 thousand UAH.

On the basis of aviary-based monitoring studies for wild ungulates MSK "Sokil" of Rivne region and SE "Hunting farm "Zvirivske" in conditions of aviary hold of fallow deer prefers willow (60.0-65.0\% of eating), rowan $(28,0-$ $30.0 \%$ ), and wild red (11.0-15.0\%). The share of spruce in the deer diet is negligible, alder is not used at all.
For the European Mouflon diet, there are herbaceous plants of the Cereal and Osaceous families, shoots of coniferous and deciduous species on the farm.

\section{Table 1}

Expenses for initial investments of the organization of the aviary complex

\begin{tabular}{lcc}
\hline \multicolumn{1}{c}{ Name of expenses } & $\begin{array}{c}\text { Quantity, } \\
\text { items }\end{array}$ & $\begin{array}{c}\text { Cost, thousand } \\
\text { UAH }\end{array}$ \\
\hline $\begin{array}{l}\text { Columns for a fence } \\
\text { Fence (fixed node mesh) }\end{array}$ & 1747 & 113.6 \\
$\begin{array}{l}\text { Goal } \\
\text { Additional elements of } \\
\text { metal structures (wire, }\end{array}$ & 7 & 21.0 \\
$\begin{array}{l}\text { angle, etc.) } \\
\begin{array}{l}\text { Operation of transport, } \\
\text { other equipment }\end{array}\end{array}$ & 26.0 \\
$\begin{array}{l}\text { Male fallow deer, deer, } \\
\text { mouflon (total) }\end{array}$ & 9 & \\
$\begin{array}{l}\text { Female fallow deer, deer, } \\
\text { mouflon (total) } \\
\text { Male boar (total) }\end{array}$ & 27 & 130.0 \\
$\begin{array}{l}\text { Female fallow deer, deer, } \\
\text { mouflon (total) }\end{array}$ & 3 & 380.0 \\
Remuneration of workers & 9 & 15.0 \\
\hline \multicolumn{1}{c}{ Total } & 50.0 \\
\hline
\end{tabular}

For the boar as well as in the "Sokil" MSC of Rivne region, SE "Zivirske" Hunting Enterprise and "PolisskeSarny" Hunting Enterprise LLC there is a wide range of feeds, which naturally includes agricultural crops (potatoes, beets, corn, sunflowers, etc.), acorns, plant rhizomes, animal feed - insect larvae, earthworms, shellfish, and more.

In the stands of forest lands, which are part of the aviary, the dominant species are willow, mountain ash, wild cherry, birch and pine with inclusions of alder belonging to medieval and arriving plantations without undergrowth and undergrowth.

According to the project of organization and development of the open-air complex of the hunting company "Polisske-Sarny", the joint holding of the fallow deer and the European mouflon is provided, as well as separate (mono-type aviaries) for wild boar and red deer. The number of fallow deer in the aviary is 20 heads, and in the case of intensive feeding -40 heads for the ratio of males and females $1: 3$. Subject to the appropriate organization of feeding in this aviary, it is possible to keep 20-35 European mouflon individuals. The number of deer and wild boar is 40 heads of each species in the enclosure. In the case of intensive feeding, the livestock population of these animals can be increased to 60 heads, respectively.

Such conditions indicate the need to improve the natural forage base by sowing one- and perennial forage crops.

The ration feed of the fallow deer in the enclosure of "Polisske-Sarny" Hunting Farm will consist of the following components:

1. Natural branch feed (cut-off residues formed during the harvesting of wood);

2. Pastures for crops (clover, alfalfa, oats);

3. Corn grain and grain mix (corn, oats, etc.);

4. Mineral feeding (salt-lizun);

5. Hay, hay and the like. 
In the middle of the aviary will be created forage fields with a total area of 3.5 hectares, of which 2.7 hectares clover, 0.3 hectares - oats; 0.5 ha - pasture ryegrass.

The optimal composition of grain mixtures for feeding fallow deer and deer contains $60-65 \%$ oats, 5-10\% wheat and $25-30 \%$ corn. It is desirable to crush grain before feeding (Kozlov \& Ovechkina, 2016).

Volumes of grain mix necessary for feeding the livestock of fallow deer, deer noble and mouflon in the aviary of LLC "Hunting economy "Polisske-Sarny" (under normal and intensive feeding conditions) in the winter and summer periods (as recommended by Kozlov \& Ovechkina, 2016) are shown in Tables 2 and 3.

The amount of grain mix required for feeding wild boar in the Polissye-Sarny hunting lodge (under normal and intensive feeding) in winter and summer (Kozlov \& Ovechkina, 2016) is summarized in Table 4.

The cost of grain required for year-round retention of deer, fallow deer and boars (UAH/1 head) in the aviary with intensive feeding is given in Table 5.

\section{Table 2}

Volumes of grain mix necessary for feeding the livestock of fallow deer in the enclosure of "Polisske-Sarny" Hunting Farm

\begin{tabular}{|c|c|c|c|c|c|c|}
\hline \multicolumn{3}{|c|}{ Winter (210 days) } & \multicolumn{3}{|c|}{ Summer period (155 days) } & \multirow[t]{2}{*}{ For the year (total) } \\
\hline \multicolumn{6}{|c|}{ The number of heads is 20} & \\
\hline Grain & $\begin{array}{l}\text { Grain consump- } \\
\text { tion, } \mathrm{kg} / \text { day }\end{array}$ & $\begin{array}{l}\text { The cost of } \\
\text { grain mixture } \\
\text { by } 1 \text { goal. }\end{array}$ & Grain & $\begin{array}{l}\text { Grain consump- } \\
\text { tion, } \mathrm{kg} / \text { day }\end{array}$ & $\begin{array}{l}\text { The cost of grain mix- } \\
\text { ture by } 1 \text { goal. per day, } \\
\text { kg }\end{array}$ & $\begin{array}{l}\text { Grain consump- } \\
\text { tion, } \mathrm{kg} / \text { year }\end{array}$ \\
\hline Oat & 16 & 0.8 & Oat & 12 & 0.6 & 5220 \\
\hline Maize & 10 & 0.5 & Maize & 5 & 0.25 & 2875 \\
\hline Wheat & 5 & 0.25 & Wheat & 2 & 0.1 & 1360 \\
\hline Total: & 31 & 1.55 & Total: & 19 & 0.95 & 9455 \\
\hline \multicolumn{7}{|c|}{ The number of heads is 40} \\
\hline Oat & 32 & 0.8 & Oat & 24 & 0.6 & 10440 \\
\hline Maize & 20 & 0.5 & Maize & 10 & 0.25 & 5750 \\
\hline Wheat & 10 & 0.25 & Wheat & 4 & 0.1 & 2720 \\
\hline Total: & 62 & 1.55 & Total: & 38 & 0.95 & 18910 \\
\hline
\end{tabular}

Table 3

Volumes of grain mix required for feeding deer herds of noble animals in the enclosure of "Polisske-Sarny" Hunting Farm

\begin{tabular}{|c|c|c|c|c|c|c|}
\hline \multicolumn{3}{|c|}{ Winter (210 days) } & \multicolumn{3}{|c|}{ Summer period (155 days) } & \multirow[t]{2}{*}{ For the year (total) } \\
\hline \multicolumn{6}{|c|}{ The number of heads is 40} & \\
\hline Grain & $\begin{array}{l}\text { Grain consump- } \\
\text { tion, } \mathrm{kg} / \text { day }\end{array}$ & $\begin{array}{l}\text { The cost of } \\
\text { grain mixture } \\
\text { by } 1 \text { goal. }\end{array}$ & Grain & $\begin{array}{l}\text { Grain consump- } \\
\text { tion, } \mathrm{kg} / \text { day }\end{array}$ & $\begin{array}{l}\text { The cost of grain mix- } \\
\text { ture by } 1 \text { goal. }\end{array}$ & $\begin{array}{c}\text { Grain consumption, } \\
\text { kg/year }\end{array}$ \\
\hline Oat & 32 & 0.8 & Oat & 24 & 0.6 & 10440 \\
\hline Maize & 20 & 0.5 & Maize & 10 & 0.25 & 5750 \\
\hline Wheat & 10 & 0.25 & Wheat & 4 & 0.1 & 2720 \\
\hline Total: & 62 & 1.55 & Total: & 38 & 0.95 & 18910 \\
\hline \multicolumn{7}{|c|}{ The number of heads is 60} \\
\hline Oat & 48 & 0.8 & Oat & 36 & 0.6 & 15660 \\
\hline Maize & 30 & 0.5 & Maize & 15 & 0.25 & 8625 \\
\hline Wheat & 15 & 0.25 & Wheat & 6 & 0.1 & 4080 \\
\hline Total: & 83 & 1.55 & Total: & 57 & 0.95 & 28365 \\
\hline
\end{tabular}

Table 4

Volumes of grain mix required for feeding wild boar in the aviary of "Polisske-Sarny" Hunting Farm

\begin{tabular}{|c|c|c|c|c|c|c|}
\hline \multicolumn{3}{|c|}{ Winter (210 days) } & \multicolumn{3}{|c|}{ Summer period (155 days) } & \multirow[t]{2}{*}{ For the year (total) } \\
\hline \multicolumn{6}{|c|}{ The number of heads is 40} & \\
\hline Grain & $\begin{array}{l}\text { Grain consump- } \\
\text { tion, } \mathrm{kg} \text { /day }\end{array}$ & $\begin{array}{l}\text { The cost of } \\
\text { grain mixture } \\
\text { by } 1 \text { goal. }\end{array}$ & Grain & $\begin{array}{l}\text { Grain consump- } \\
\text { tion, } \mathrm{kg} / \text { day }\end{array}$ & $\begin{array}{l}\text { The cost of grain mix- } \\
\text { ture by } 1 \text { goal. }\end{array}$ & $\begin{array}{c}\text { Grain consumption, } \\
\mathrm{kg} / \text { year }\end{array}$ \\
\hline Oat & 60 & 1.5 & Oat & 60 & 1.5 & 21900 \\
\hline Maize & 28 & 0.7 & Maize & 28 & 0.7 & 10220 \\
\hline Total: & 88 & 2.2 & Total: & 88 & 2.2 & 32120 \\
\hline \multicolumn{7}{|c|}{ The number of heads is 60} \\
\hline Oat & 90 & 1.5 & Oat & 90 & 1.5 & 32850 \\
\hline Maize & 42 & 0.7 & Maize & 42 & 0.7 & 15330 \\
\hline Total: & 132 & 2.2 & Total: & 132 & 2.2 & 48180 \\
\hline
\end{tabular}


Table 5

Calculation of the cost of grain required for preparation of grain mix for deer and fallow deer/boars in the aviary of "PolisskeSarny" Hunting Farm during intensive feeding of animals

\begin{tabular}{ccccc}
\hline Grain & Grain weight is calculated, kg & Cost, UAH/kg & Total value of grain, UAH & Grain cost per head \\
\hline Oat & $26100 / 32850$ & 3.5 & $91350.00 / 114975.00$ & $913.5 / 1916.25$ \\
Maize & $14375 / 15330$ & 4.6 & $66125.00 / 70518.00$ & $661.25 / 1175.3$ \\
Wheat & 6800 & 3.7 & 25160.00 & 251.6 \\
Total: & $47275 / 47275$ & & $182635.00 / 185493.00$ & $1826.35 / 3091.55$ \\
\hline
\end{tabular}

There are no natural water sources. The enclosure is equipped with an artificial watering hole, which is filled with artesian wells by means of a water supply system.

According to the results of the analysis of the investigated water, samples taken during 2017-2018 it was found that the investigated indices in general met the requirements of DSanPiN 2.2.4-171-10 "Hygienic requirements for drinking water intended for human consumption". In particular, the $\mathrm{pH}$ is determined in the range of $7.1-7.5 \mathrm{mg} / \mathrm{dm}^{3}$; turbidity 0.95-1.15 mg/dm 3 , chloride content - 7.3-7.4 mg/dm sulfates - 17.7-17.9 $\mathrm{mg} / \mathrm{dm}^{3}$, manganese $-0.01 \mathrm{mg} / \mathrm{dm}^{3}$, cobalt - up to $0.1 \mathrm{mg} / \mathrm{m}^{3}$, copper $-0.245-0.254 \mathrm{mg} / \mathrm{dm}^{3}$, permanganate oxidation $-1.0-1.1 \mathrm{mgO}_{2} / \mathrm{dm}^{3}$, the number of microorganisms in $1 \mathrm{~cm}^{3}$ of water is less than 100, the bacteria of the group of Escherichia coli are absent. However, it is worth noting the increased iron content $-0.34-0.36 \mathrm{mg} / \mathrm{dm}^{3}$, which was 1.8 times higher than the norm and nitrates $1.05-1.15 \mathrm{mg} / \mathrm{dm}^{3}$, which is 2.1 times higher than the norm.

The main direction of use of the hunting complex of "Polisske-Sarny" Hunting Farm Ltd. is to raise animals for release into their own lands and to sell livestock to other users of hunting grounds. According to the Hunting Regulations, the annual increase in fallow deer is $10-20 \%$ and the average annual growth rate is $15 \%$. Due to the fact that in the aviary, in comparison with free populations, the effect of adverse environmental factors is much lower (there are no predators, sanitary and preventive measures are carried out, animals are provided with water and feed, shelters from weather and climatic conditions, etc.), the minimum factor of disturbance during the year, etc., it is possible to achieve a $20 \%$ increase in the number of livestock due to the maximum preservation of young animals and the formation of the main herd of high quality nurseries of both sexes.

With the number of the main reproductive stock of 20 heads, including 4 males and 16 females, it is possible to get about 20-22 heads of young (on average $0.8-1.4$ goals per 1 adult female.) From the sale of the young stock to other farms the annual income will be 280-320 thousand UAH. There may also be income from the sale to the restaurant chain of meat of animals that have deviations from the characteristic phenotype (atypical color, males with irregular horns, etc.) whose participation in reproduction is undesirable. By the beginning of winter, it is advisable to leave only young animals in the main herd to be used for livestock repairs, which will help to rejuvenate the herd and reduce the cost of feeding it.

\section{Conclusions}

For the development and distribution of open-air keeping and breeding of wild ungulates and the further development of this type of activity it is necessary to apply a set of measures, among which special attention should be paid to the implementation of a complex of zoohygienic and eco- nomic measures. The total amount of capital investments for the construction of the aviary complex, including the costs for the purchase of the main livestock of the captives and the construction, is from 1337.1 thousand UAH. As a result of the sale of meat, you can receive from 39.43 thousand UAH. profit per year. Taking into account the costs of initial investments for the creation of the aviary complex, the payback period is 3 years.

Prospects for further research. Our further research will be focused on tax calculations, purchase of a press extruder, adjustment of processing of the received production on the farm, improvement of trophic qualities of male fallow deer and red deer.

\section{Conflict of interest}

The authors declared that there is no conflict of interest.

\section{References}

Bilyi, V. V. (2007). O volernom razvedenii dikikh svinei [About aviary breeding of wild pigs]. Sovremennye problemy prirodopolzovania, okhotovedenia i zverovodstva-Modern problems of nature management, hunting and animal farming, 1, 48-49. https://cyberleninka.ru/article/n/o-voliernomrazvedenii-dikih-sviney/viewer (in Russian).

Evtushevskyi, M. N. (2012). Myslyvski tvaryny Ukrainy na voli ta $\mathrm{v}$ volerakh [Hunting animals of Ukraine at freedom and in aviaries]. Cherkasy: Vertykal (in Ukrainian).

Kozlov, V. M., \& Ovechkina, N. N. (2016). Osobennosti kormlenia kopytnykh (Cervus elaphus L., Dama dama L., Sus scrofa L.) v usloviakh volernoho soderzhania [Peculiarities of feeding of animals in erclosuses]. Mezdunarodnyi nauchnyi zhurnal - International research journal, 6(48), 5, 16-19. doi: 10.18454/IRJ.2016.48.017 (in Russian).

Nastanova z uporiadkuvannia myslyvskykh ukhid. 2002: Kyiv: Derzhavnyi komitet lisovoho hospodarstva Ukrainy (in Ukrainian).

Pepko, V. O. (2019). Sanitarno-hihienichna otsinka hruntiv ta dzhelel vodopostachannia na etapi stvorennia volernoho hospodarstva [Sanitary and higienic assessment of soils and water supply sources at the deploy of the aviary household]. Tavriiskyi naukovyi visnyk - Taurida Scientific Herald, 107, 217222. doi: 10.32851/2226-0099.2019.107.31 (in Ukrainian).

Volokh, A. M. (2001). Poluvolnoe soderzhanie i vyrashchivanie dikikh kopytnykh $\mathrm{s}$ tseliu povyshenia ekonomicheskoi effektivnosti zhivotnovodstva [Semi-free maintenance and breeding of wild ungulates in purpose to increase the economic efficiency of stockbreeding]. Visnyk ahrarnoi nauky Prychornomoria Ukrainian Black Sea region agrarian science, 3(12), 2, 393-400. http://elar.tsatu.edu.ua/handle/123456789/4108 (in Russian).

Volokh, A. M. (2015). Napivvilne vyroshchuvannia dykykh tvaryn yak alternativa tradytsiinomu tvarynnytstvu i myslyvstvu [Semifree wildlife farming as an alternative to traditional animal husbandry and hunting]. 4-yi Vseukrainskyi congtes ecologiv $z$ miszhnarodnoiu uchastiu - 4th All-Ukrainian congress of ecologists with international participation, 149 (in Ukrainian).

Volokh, A. M. (2016). Okhotnichi zveri stepnoi Ukrainy [Mammals hunted in steppe Ukraine]. Kherson: Grinn D.S. (in Russian). 